\title{
Development Of Multi-Criteria Decision Making Model In Packed Beverage Industry Using Global Criterion Method
}

\section{Pengembangan Model Pengambilan Keputusan Multi Kriteria Pada Industri Minuman Kemasan Menggunakan Global Criterion Method}

\author{
Sutrisno ${ }^{1}$, Puryani ${ }^{1}$ \\ ${ }^{1}$ Department of Industrial Engineering, Faculty of Industrial Engineering, Universitas Pembangunan Nasional \\ Veteran Yogyakarta \\ Jl. SWK Jl. Ring Road Utara No. 104 Yogyakarta, 55283 \\ email :trisno_upnyk@yahoo.co.id \\ doi: https://doi.org/10.31315/opsi.v14i2.5365
}

Received: $16^{\text {th }}$ August 2021; Revised: $26^{\text {th }}$ October 2021; Accepted: $1^{\text {st }}$ November 2021; Available online: $21^{\text {st }}$ December 2020; Published regularly: December 2021

\begin{abstract}
The packaged beverage industry with various brands has appeared on the market. The number of competitors in the market requires the packaged beverage industry to implement the right strategy to win the competition. One strategy that can be applied is to make savings and maximize the use of company resources. One of the savings that can be done is to minimize production costs, while maximizing the use of resources can be done by maximizing the utility of the machine owned by the company. Efforts to minimize production costs can be contradictory to efforts to maximize machine utility, this is because maximizing machine utility will certainly require additional production costs, even though the company also wants to minimize production costs. This is included in the category of multi-criteria decision-making problems. To facilitate the company's management in achieving these contradictory company goals, this study will develop a multi-criteria decision-making model to assist companies in making optimal decisions regarding these contradictory company goals. The multi-criteria decision-making model developed is a mathematical model consisting of two mutually contradictory objective functions, namely minimizing production costs and maximizing machine utility, as well as problem constraints which are limitations that are owned by the company in optimizing the achievement of these contradictory company goals. To optimize the multi-criteria decision-making model that has been developed, it will use the global criterion method. The global criterion method will produce a compromise solution that has a minimum deviation from the ideal value of each objective function. Using the global criterion method, a production plan that minimizes production costs and maximizes machine utility is obtained. The multi-criteria decision-making model developed will cause the production plan to have a small deviation from the actual demand, because the model development involves forecasting product demand. The developed model will also produce a production plan that will not exceed the warehouse capacity, so that product storage costs can be minimized, this is because the developed model includes warehouse capacity as a barrier.
\end{abstract}

Keywords: bottled beverage industry, multi-criteria decision making, global criterion method

\section{ABSTRAK}

Industri minuman kemasan dengan berbagai merek telah banyak muncul di pasaran. Banyaknya pesaing di pasaran mengharuskan industri minuman kemasan untuk menerapkan strategi yang tepat untuk memenangkan persaingan. Salah satu strategi yang dapat diterapkan adalah melakukan penghematan dan memaksimalkan penggunaan sumber daya perusahaan. Salah satu penghematan yang dapat dilakukan adalah dengan meminimasi biaya produksi, sedangkan memaksimalkan penggunaan sumber daya dapat dilakukan dengan memaksimalkan utilitas mesin yang dipunyai oleh perusahaan. Upaya meminimasi biaya produksi dapat menjadi kontradiktif terhadap upaya memaksimalkan utilitas mesin, hal tersebut dikarenakan dalam melakukan maksimalisasi utilitas 
mesin tentunya akan membutuhkan biaya produksi tambahan, padahal perusahaan juga berkeinginan untuk meminimasi biaya produksi. Hal ini termasuk dalam kategori permasalahan pengambilan keputusan multi kriteria. Untuk mempermudah manajemen perusahaan dalam mencapai tujuan perusahaan yang saling kontradiktif tersebut maka penelitian ini akan mengembangkan model pengambilan keputusan multi kriteria untuk membantu perusahaan dalam mengambil keputusan yang optimal terhadap tujuan perusahaan yang saling kontradiktif tersebut. Model pengambilan keputusan multi kriteria yang dikembangkan adalah model matematika yang terdiri dari dua fungsi tujuan yang saling kontradiktif, yaitu minimasi biaya produksi dan maksimasi utilitas mesin, serta pembatas masalah yang merupakan batasan yang dipunyai oleh perusahaan dalam mengoptimalkan pencapaian tujuan perusahaan yang saling kontradiktif tersebut. Untuk melakukan optimasi terhadap model pengambilan keputusan multi kriteria yang telah dikembangkan akan dilakukan menggunakan global criterion method. Global criterion method akan menghasilkan solusi kompromi yang mempunyai deviasi yang minimal terhadap nilai ideal dari masing-masing fungsi tujuan. Menggunakan global criterion method maka diperoleh perencanaan produksi yang meminimalkan biaya produksi dan memaksimalkan utilitas mesin. Model pengambilan keputusan multi kriteria yang dikembangkan akan menyebabkan rencana produksi mempunyai deviasi yang kecil terhadap permintaan actual, karena dalam pengembangan model melibatkan peramalan permintaan produk. Model yang dikembangkan juga akan menghasilkan rencana produksi yang tidak akan melebihi kapasitas gudang, sehingga biaya simpan produk dapat diminimasi, hal ini dikarenakan model yang dikembangkan memasukkan kapasitas gudang sebagai suatu pembatas.

Kata Kunci: industry minuman kemasan, pengambilan keputusan multi kriteria, global criterion method

\section{PENDAHULUAN}

\subsection{Latar Belakang Masalah}

Industri minuman kemasan sekarang ini telah tumbuh dengan pesat. Industri minuman kemasan baru dengan berbagai merek telah muncul di pasaran untuk meramaikan persaingan. Munculnya banyak pesaing, mengharuskan industri minuman kemasan untuk menerapkan suatu strategi untuk bertahan hidup sekaligus memenangkan persaingan. Salah satu strategi tersebut adalah melakukan penghematan dan memaksimalkan penggunaan sumber daya.

Penghematan yang dilakukan pada suatu industri, dapat menjadi kontradiktif terhadap pemaksimalan penggunaan sumber daya. Hal ini dikarenakan penggunaan sumber daya pada suatu industri, misalkan penggunaan mesin akan membutuhkan biaya operasional, padahal suatu industri harus melakukan penghematan.

Permasalahan penghematan di suatu industry yang kontradiktif dengan pemaksimalan penggunaan sumber daya termasuk dalam kategori permasalahan pengambilan keputusan multi kriteria. Permasalahan pengambilan keputusan multi kriteria ditandai adanya tujuan-tujuan yang saling berkonflik pada suatu permasalahan yang akan dicari penyelesaiannya. Arti dari tujuantujuan yang saling berkonflik adalah pengoptimalan nilai dari suatu fungsi tujuan akan menurunkan tingkat optimalitas dari fungsi tujuan yang lainnya. (Indrianti dan Sutrisno, 2014).

Salah satu penghematan dalam suatu industry adalah dengan meminimalkan biaya produksi, sedangkan pemaksimalan penggunaan sumber daya salah satunya dapat dilakukan dengan memaksimalkan utilitas mesin. Untuk meningkatkan daya saing suatu industri minuman kemasan maka perlu dilakukan minimasi biaya produksi dengan sekaligus memaksimalkan utilitas mesin yang dipunyai. Untuk melakukan minimasi biaya produksi dengan sekaligus memaksimalkan utilitas mesin maka manajemen perusahaan harus melakukan suatu kebijakan untuk mencapai dua tujuan perusahaan yang saling kontradiktif tersebut secara optimal. Optimasi terhadap tujuan perusahaan yang saling kontradiktif atau berkonflik ini merupakan permasalahan pengambilan keputusan multi kriteria. Untuk mempermudah manajemen perusahaan dalam melakukan pengambilan keputusan terhadap tujuan perusahaan yang saling berkonflik maka perlu dikembangkan model pengambilan keputusan multi criteria.

Pada penelitian ini akan dikembangkan suatu model pengambilan keputusan multi criteria untuk melakukan optimasi terhadap dua tujuan yang saling berkonflik pada industri minuman kemasan, yaitu minimasi biaya produksi dan maksimasi utilitas mesin, dengan pembatas berupa keterbatasan sumber daya perusahaan untuk mencapai tujuan-tujuan tersebut. Untuk melakukan optimasi terhadap 
model pengambilan keputusan multi kriteria yang dikembangkan, akan dilakukan menggunakan global criterion method. Kelebihan metode ini jika dibandingkan dengan teknik-teknik pengambilan keputusan multi kriteria lainnya adalah adanya solusi kompromi (trade-off) yang dihasilkan mempunyai deviasi yang minimum jika dibandingkan dengan solusi ideal dari masing-masing fungsi tujuan.. (Indrianti dan Sutrisno, 2014).

Optimasi pada model pengambilan keputusan multi criteria yang dilakukan akan menghasilkan biaya produksi yang minimal dan utilitas mesin yang maksimal. Hasil optimasi tersebut diharapkan dapat meningkatkan daya saing industry minuman kemasan dalam persaingan di pasaran global Model pengambilan keputusan multi kriuteria yang dikembangkan akan menghasilkan rencana produksi yang mempunyai deviasi yang kecil terhadap permintaan actual, karena dalam pengembangan model akan melibatkan peramalan permintaan produk. Model pengambilan keputusan multi kriteria yang dikembangkan juga akan menghasilkan rencana produksi yang tidak akan melebihi kapasitas gudang, sehingga akan meminimalkan biaya simpan, hal ini dikarenakan kapasitas gudang akan dilibatkan sebagai pembatas pada model yang dikembangkan.

\subsection{Rumusan Masalah}

Rumusan masalah pada penelitian ini adalah bagaimana mengembangkan model pengambilan keputusan multi kriteria pada industri minuman kemasan untuk meminimalkan biaya produksi dan memaksimalkan utilitas mesin?

\subsection{Tujuan Penelitian}

Tujuan dari penelitian ini adalah mengembangkan model pengambilan keputusan multi kriteria pada industri minuman kemasan untuk meminimalkan biaya produksi dan memaksimalkan utilitas mesin menggunakan global criterion method.

\subsection{Tinjauan Pustaka}

\section{a) Pengambilan keputusan multi kriteria}

Pengambilan keputusan multikriteria (Multiple Criteria Decision Making) adalah suatu metode proses pemilihan altematif untuk mendapatkan solusi optimal dari beberapa altematif keputusan dengan memperhitungkan kriteria atau objektif yang lebih dari satu yang berada dalam situasi yang bertentangan (conflicting). Paradigma ini berbeda dengan cara pandang tradisonal problem pencarian solusi optimal suatu keputusan. Problem keputusan yang kompleks dimodelkan hanya sebagai problem sederhana dari model optimasi keputusan berobjektif tunggal.Sehingga terjadi simplikasi rialitas problem yang berlebihan, akhimya solusi keputusan gagal mencari solusi permasalahan yang sebenamya. Artinya pendekatan model optimasi pendekatan tunggal gagal mengakomodasikan "heterogenitas", dinamika dan kondisi kriteria yang mengalami konflik tersebut.(Huang et.al., 2011).

$\mathrm{Si}$ et.al (2016) membagi taksonomi keilmuan pengambilan keputusan multi kriteria menjadi 2 pendekatan yang berbeda yaitu : Multiple Objecvtive Decision Making (MODM) dan Multiple Atribute Decision Making (MADM). Masing-masing memiliki karakter, atribut, dan sifat, serta aplikasi penyelesai ragam persoalan keputusan yang berbeda

\section{b) Pendekatan MODM}

Pendekatan MODM berkenaan dengan penyelesaian model optimasi yang memiliki objektif majemuk dan objektifnya bersifat saling mengalami konflik. Keberadaan adanya solusi "optimal" atau trade-off untuk objektif yang majemuk ini akan menjadi pembeda dengan pendekatan optimasi klasik objektif tunggal semacam linier programming. Pada metoda MODM, aktivitas keputusan yang dirupakan sebagai variabel keputusan yang dicari (varibel kontinu) tidak ditetapkan terlebih dahulu. Fungsi objektif yang berjumlah lebih dari dua objektif yang harus dioptimalkan secara simultant dan kendala sistem keputusan dibentuk dari variabel ini (Cinelli et. al, 2014).

Teknik-teknik pengambilan keputusan multi kriteria yang dapat digunakan untuk menyelesaikan permasalahan MODM diantaranya adalah single objective approach, unifying objective function approach (global criterion method, minimum deviation method, utility function method, dan compromise constraint method), goal programming, interactive approach (step method dan game theoretic technique), dan compromise programming. 


\section{c) Pendekatan MADM}

Secara metodologis perbedaan metode MADM dalam penggunaannya didasarkan cara melakukan agregasi dari kriteria pilihan (Jiang et.al. ,2009) yaitu: (i) Pendekatan sintesis yang membentuk fungsi kriteria tunggal dari berbagai kriteria yang yang bisa diperbandingkan (agregation complete transitive); Pendekatan "outranking", dengan menerima perankingan dalam kriteria agregasi yang terpisah (agnation partiale); (iii) Pendekatan dengan judgement lokal dan interaktif (agregation locale / iterative).

Pendekatan cara melakukan agregasi fungsi kriteria memunculkan berbagai perbedaan pandangan diantara peneliti multikriteria, yaitu antara pendekatan "ecole americain" (seperti contoh metoda AHP, MAUT, dan lainnya) yang mewakili pendekatan sintesis dan "ecole francophone" yang mewakili pendekatan agregasi parsial yaitu metode outranking (contohnya metoda ELECTRE, PROMETHE dan lainnya).(Handayani dan Wakhidah, 2012).

\section{d) Global criterion method}

Global criterion method adalah salah satu metode penyelesaian permasalahan multi objective dalam permasalahan pengambilan keputusan multi criteria. Global criterion method merupakan salah satu metode dari beberapa metode yang termasuk dalam kelompok unifying objective function approach. Prinsip dari global criterion method adalah membuat fungsi tujuan global yang meminimalkan total deviasi nilai fungsi tujuan individu terhadap nilai-nilai ideal (sebagai rasio terhadap nilai-nilai ideal.(Indrianti dan Sutrisno, 2014).

Model optimasi global criterion method adalah:

$\operatorname{Min} F=\sum_{\ell=1}^{k}\left[\frac{f_{\ell}\left(x^{*}\right)-f_{\ell}(x)}{f_{\ell}\left(x^{*}\right)}\right]^{p}$

pembatas

$$
\begin{aligned}
& g_{i}(x) \leq 0, i=1,2, \ldots, m \\
& x \geq 0
\end{aligned}
$$

dengan :

$f_{\ell}\left(x^{*}\right)$ : nilai fungsi tujuan $\ell$ pada kondisi optimal individu $x^{*}$

$\mathrm{p}$ : eksponen bernilai integer yang menggambarkan kepentingan tujuan.

\section{e) State of the art}

Safrizal dan Tanti (2016) melakukan penelitian yang termasuk dalam kategori MADM menggunakan metode AHP dengan objek lembaga Pendidikan. Amin dan Mustika (2017) melakukan penelitian yang termasuk dalam kategori MADM menggunakan metode ANP dengan objek investasi. Abdullah (2018) melakukan penelitian yang termasuk dalam kategori MADM menggunakan metode AHP dengan objek industry manufaktur. Doally dkk (2019) melakukan penelitian yang termasuk dalam kategori MADM menggunakan metode Fuzzy AHP dan TOPSIS dengan objek industry fashion. Kurniawan dkk (2020) melakukan penelitian yang termasuk dalam kategori MADM menggunakan metode SAW dengan objek masalah social. Penelitian ini akan mengembangkan model pengambilan keputusan multi kriteria yang termasuk dalam kategori MODM menggunakan global criterion method dengan objek industri minuman kemasan.

\section{METODE PENELITIAN}

\subsection{Obyek Penelitian}

Objek dari penelitian ini adalah Perusahaan Minuman Kemasan X.

\subsection{Tipe dan Sumber Data}

Data yang dibutuhkan pada penelitian ini terdiri dari dua jenis data, yaitu:

\section{1) Data Primer}

Data primer pada penelitian ini adalah data waktu proses produksi yang didapatkan dengan melakukan pengamatan secara lengsung di lantai produksi.

\section{2) Data sekunder}

Data sekunder pada penelitian ini adalah data permintaan produk, data biaya produksi, data ketersediaan jam kerja, dan data kapasitas gudang.

\subsection{Kerangka Penelitian}

Kerangka penelitian dapat dilihat pada Gambar 1. 


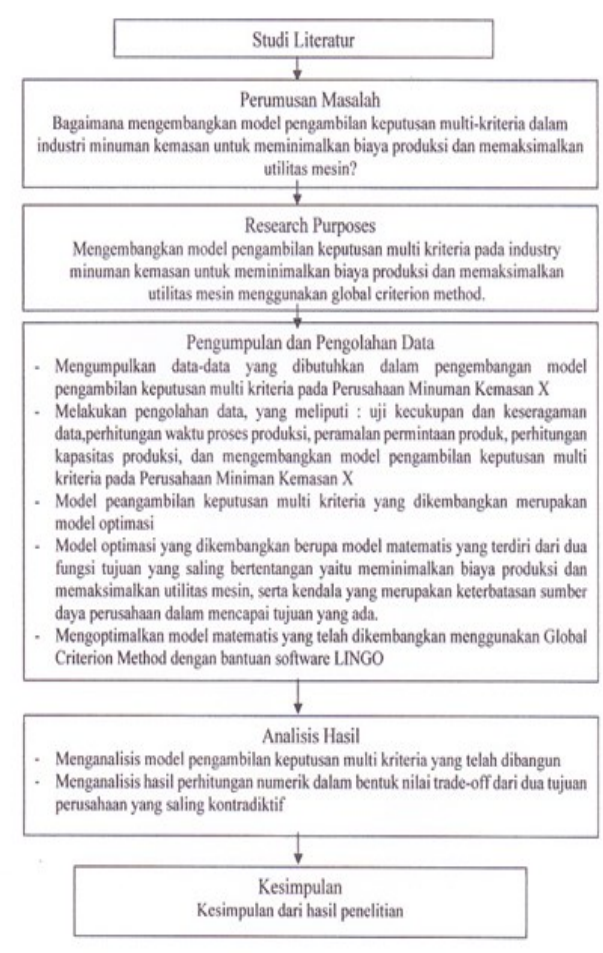

Gambar 1. Kerangka penelitian

\section{HASIL DAN PEMBAHASAN}

\subsection{Pengumpulan Data}

Data yang dibutuhkan untuk membangun model pengambilan keputusan multi kriteria pada Perusahaan Minuman Kemasan X adalah data waktu proses produksi, data permintaan produk, data biaya produksi, data penjualan produk, data ketersediaan jam kerja, dan data kapasitas gudang. Data waktu proses produksi terdiri dari waktu perebusan, pengemasan kedalam cup (gelas), hingga pengemasan ke dalam kardus. Data waktu proses produksi didapatkan dari pengamatan secara langsung pada lantai produksi Untuk data-data lainnya diperoleh dari dokumen perusahaaan. Data biaya produksi mencakup data biaya bahan baku utama, biaya bahan kemas, upah pekerja borongan dan harian, upah staff kantor, serta biaya untuk keperluan rutin harian seperti pemakaian listrik dan kayu bakar. Shift kerja karyawan terdiri dari dua shift dengan masingmasing shift terdiri dari 7 jam kerja produktif. Kapasitas gudang/warehouse yang dimiliki perusahaan ditentukan berdasarkan luas ruangan yang digunakan untuk penyimpanan. Gudang berisi palet yang digunakan sebagai alas tumpukan karton untuk memudahkan dalam memindahkan karton. Setiap satu palet dapat menampung 130 karton minuman kemasan yang disesuaikan dengan beban maksimal yang diperbolehkan.

Perusahaan Minuman Kemasan X mempunyai delapan jenis produk minuman kemasan. Yang menjadi objek dalam penelitian ini adalah kedelapan jenis produk minuman kemasan tersebut. Produk minuman kemasan yang dihasilkan diproses melalui tiga stasiun kerja, yaitu stasiun kerja perebusan, stasiun kerja penuangan cup, dan stasiun kerja pengemasan karton. Proses produksi minuman kemasan pada Perusahaan Minuman Kemasan X dimulai dengan melakukan proses perebusan menggunakan dua tangka besar yang dapat menampung formula minuman dengan kapasitas maksimal 1000 liter/tangki. Setelah selesai melakukan proses perebusan, selanjutnya hasil perebusan memasuki stasiun penuangan cup untuk dituangkan ke cup plastik menggunakan mesin press kemasan yang menampung cup kosong sebanyak $6 \times 4$ cup. Setelah selesai melakukan penuangan cup, proses terakhir adalah memasukan cup minuman yang berada

Tabel 1. Data rangkuman uji kecukupan data proses perebusan

\begin{tabular}{cccccccc}
\hline Produk & $\boldsymbol{\Sigma} \boldsymbol{X}$ & $\boldsymbol{\Sigma}\left(\boldsymbol{X}^{\mathbf{2}}\right)$ & $\mathbf{N}$ & $\mathbf{K}$ & $\mathbf{S}$ & $\mathbf{N}^{\prime}$ & Ket \\
\hline Minuman A & 253,873 & 3236,209 & 20 & 2 & 0,05 & 17,090 & Cukup \\
Minuman B & 256,018 & 3247,749 & 20 & 2 & 0,05 & 13,171 & Cukup \\
Minuman C & 267,217 & 3576,809 & 20 & 2 & 0,05 & 12,107 & Cukup \\
Minuman D & 309,300 & 4809,166 & 20 & 2 & 0,05 & 10,651 & Cukup \\
Minuman E & 317,433 & 5059,926 & 20 & 2 & 0,05 & 18,041 & Cukup \\
Minuman F & 312,683 & 4965,864 & 20 & 2 & 0,05 & 15,635 & Cukup \\
Minuman G & 245,417 & 2997,454 & 20 & 2 & 0,05 & 18,212 & Cukup \\
Minuman H & 239,700 & 2898,106 & 20 & 2 & 0,05 & 17,609 & Cukup \\
\hline
\end{tabular}


pada conveyor yang berjalan untuk dikemas ke dalam karton.

\subsection{Pengolahan Data}

\section{1) Uji Kecukupan Data}

Perusahaan Minuman Kemasan X mempunyai tiga stasiun kerja yaitui, stasiun kerja perebusan, stasiun kerja penuangan cup, dan stasiun kerja pengemasan karton. Uji kecukupan data dilakukan untuk memastikan bahwa data yang dikumpulkan sudah cukup mewakili data proses produksi secara keseluruhan. Uji kecukupan data dilakukan terhadap pengumpulan data waktu proses perebusan, data waktu proses penuangan cup, dan waktu pengemasan karton.

\section{2) Uji Keseragaman Data}

Uji keseragaman data (Tabel 2) dilakukan untuk memastikan bahwa data yang dikumpulkan tidak ada yang merupakan data terpencil, yang nantinya dapat mengakibatkan kesalahan dalam penarikan kesimpulan terhadap data yang sudah dikumpulkan. Uji keseragaman data dilakukan terhadap pengumpulan data waktu proses perebusan, data waktu proses penuangan cup, dan waktu pengemasan karton.

Tabel 2. Data rangkuman uji keseragaman data proses perebusan

\begin{tabular}{cccccl}
\hline Produk & $\overline{\boldsymbol{X}}$ & $\sigma$ & BKA & BKB & Ket \\
\hline Minuman A & 12,649 & 1,201 & 15,253 & 10,045 & Seragam \\
Minuman B & 12,701 & 1,065 & 14,878 & 10,522 & Seragam \\
Minuman C & 13,311 & 1,124 & 15,877 & 10,745 & Seragam \\
Minuman D & 15,460 & 1,126 & 17,926 & 12,995 & Seragam \\
Minuman E & 15,822 & 1,549 & 19,174 & 12,471 & Seragam \\
Minuman F & 15,684 & 1,523 & 18,763 & 12,605 & Seragam \\
Minuman G & 12,171 & 1,267 & 14,762 & 9,580 & Seragam \\
Minuman H & 11,960 & 1,312 & 14,608 & 9,312 & Seragam \\
\hline
\end{tabular}

Tabel 3. Rangkuman waktu siklus proses perebusan

\begin{tabular}{ccc}
\hline No. & Produk & Waktu Siklus (menit) \\
\hline 1 & Minuman A & 12,376 \\
2 & Minuman B & 12,706 \\
3 & Minuman C & 13,401 \\
4 & Minuman D & 15,476 \\
5 & Minuman E & 15,856 \\
6 & Minuman F & 15,696 \\
7 & Minuman G & 12,156 \\
8 & Minuman H & 11,987 \\
\hline
\end{tabular}

\section{3) Perhitungan Waktu Siklus}

Perhitungan waktu siklus terdiri dari waktu siklus proses perebusan, waktu siklus proses penuangan cup, dan waktu siklus pengemasan karton (Tabel 3).

\section{4) Perhitungan Performance Rating}

Perhitungan faktor penyesuaian berfungsi untuk menentukan seberapa besar kemampuan pekerja dalam melakukan pekerjaan. Faktor penyesuaian yang dihitung menghasilkan performance rating sebagai penambahan waktu yang disesuaikan dengan kemampuan pekerja.

Pada stasiun kerja perebusan dan penuangan cup, seluruh pengerjaan dilakukan dengan mesin sedangkan operator hanya memantau mesin apabila terdapat terdapat hal yang tidak terduga. Sehingga performance rating untuk stasiun kerja perebusan dan penuangan cup ditentukan sebesar 1, karena dianggap mampu bekerja dengan baik. Perhitungan faktor penyesuaian untuk proses pengemasan menggunakan cara westinghouse dan obyektif.

Perhitungan performance rating untuk proses pengemasan karton adalah sebagai berikut: $\quad \mathrm{Rf}=\mathrm{P} 1 \times \mathrm{P} 2$

$\mathrm{Rf}=1,14 \times 1,12$

$\mathrm{Rf}=1,277$

Maka performance rating yang digunakan untuk waktu proses pekerja pada stasiun kerja pengemasan karton sebesar 1,277.

\section{5) Perhitungan Waktu Normal}

Waktu normal dihitung berdasarkan pada waktu siklus dengan mempertimbangkan performance rating. Waktu normal yang dihitung adalah waktu normal proses perebusan, waktu proses penuangan cup, dan waktu proses pengemasan karton.

Tabel 4. Rangkuman waktu normal proses

\begin{tabular}{ccc} 
perebusan & \\
\hline Produk & $\begin{array}{c}\text { Waktu } \\
\text { Siklus } \\
\text { (menit) }\end{array}$ & $\begin{array}{c}\text { Waktu } \\
\text { Normal } \\
\text { (menit) }\end{array}$ \\
\hline Minuman A & 12,376 & 12,376 \\
Minuman B & 12,706 & 12,706 \\
Minuman C & 13,401 & 13,401 \\
Minuman D & 15,476 & 15,476 \\
Minuman E & 15,856 & 15,856 \\
Minuman F & 15,696 & 15,696 \\
Minuman G & 12,156 & 12,156 \\
Minuman H & 11,987 & 11,987 \\
\hline
\end{tabular}




\section{6) Perhitungan Allowance}

Faktor kelonggaran diberikan kepada pekerja maupun mesin sebagai waktu toleransi terhadap kebutuhan pribadi maupun kendalakendala yang tidak terduga.

Tabel 5. Rangkuman allowance seluruh stasiun kerja

\begin{tabular}{clc}
\hline No. & Stasiun Kerja & Allowance \\
\hline 1 & Perebusan & $8 \%$ \\
2 & Penuangan & $5 \%$ \\
3 & Pengemasan & $8 \%$ \\
\hline
\end{tabular}

\section{7) Perhitungan Waktu Baku}

Waktu baku menjadi waktu standar yang diberikan untuk suatu proses maupun pekerjaan dengan mempertimbangkan waktu normal dan faktor penyesuaian yang diberikan untuk menyelesaikan suatu pekerjaan tertentu.

Tabel 6. Rangkuman waktu baku proses perebusan

\begin{tabular}{lc}
\hline \multicolumn{1}{c}{ Produk } & Waktu Baku (menit) \\
\hline Minuman A & 13,45 \\
Minuman B & 13,81 \\
Minuman C & 14,57 \\
Minuman D & 16,82 \\
Minuman E & 17,23 \\
Minuman F & 17,06 \\
Minuman G & 13,21 \\
Minuman H & 13,03 \\
\hline
\end{tabular}

\section{8) Perhitungan Biaya Produksi}

Biaya produksi meliputi tarif tunggal, biaya overhead yang dibebankan pada produk, dan biaya kebutuhan bahan kemas.

Tabel 7. Biaya produksi masing-masing jenis produk

\begin{tabular}{ccc}
\hline No. & Produk & Biaya Produksi/Karton \\
\hline 1 & Minuman A & Rp 6.576 \\
2 & Minuman B & Rp 6.783 \\
3 & Minuman C & Rp 6.809 \\
4 & Minuman D & Rp 12.125 \\
5 & Minuman E & Rp 11.907 \\
6 & Minuman F & Rp 12.231 \\
7 & Minuman G & Rp 12.407 \\
8 & Minuman H & Rp 11.875 \\
\hline
\end{tabular}

\section{9) Peramalan Permintaan}

Melakukan tahapan-tahapan peramalan permintaan produk minuman kemasan pada Perusahaan Minuman Kemasan X. Peramalan permintaan dilakukan dalam 12 periode dalam satuan minggu dari Januari 2021 sampai Maret 2021. Dari peramalan permintaan produk pada akhirnya dapat dilakukan penentuan jadwal induk produksi.

Tabel 8. Jadwal induk produksi bulan Januari 2021

Januari 2021

\begin{tabular}{|c|c|c|c|c|}
\hline Produk & $\begin{array}{c}\text { Minggu } \\
\text { Ke } 1 \\
\end{array}$ & $\begin{array}{c}\text { Minggu } \\
\text { Ke } 2 \\
\end{array}$ & $\begin{array}{c}\text { Minggu } \\
\text { Ke } 3 \\
\end{array}$ & $\begin{array}{c}\text { Minggu } \\
\text { Ke } 4 \\
\end{array}$ \\
\hline Minuman A & - & 20.457 & 18.458 & 22.807 \\
\hline Minuman B & - & 2.543 & 2.497 & 2.785 \\
\hline Minuman C & - & 1.742 & 1.623 & 1.849 \\
\hline Minuman D & - & 1.928 & 1.809 & 2.128 \\
\hline Minuman E & - & 554 & 521 & 592 \\
\hline Minuman F & - & 753 & 721 & 826 \\
\hline Minuman $\mathrm{G}$ & - & 321 & 312 & 356 \\
\hline Minuman $\mathrm{H}$ & - & 234 & 205 & 249 \\
\hline Jumlah & $\mathbf{0}$ & 28.532 & 26.146 & 31.592 \\
\hline
\end{tabular}

\section{0) Perhitungan Kapasitas Proses Produksi}

Perhitungan total kapasitas setiap stasiun kerja didasarkan pada jumlah mesin maupun pekerja dengan kapasitas yang tersedia serta dengan penggunaan waktu set up sebanyak 10 menit setiap satu shift dengan asumsi produksi terus berjalan selama hari kerja. Kapasitas proses perebusan $=8.200 \mathrm{menit} / \mathrm{minggu}$. Kapasitas proses penuangan cup $=8.200$ menit/minggu., Kapasitas proses pengemasan karton $=57.400 \mathrm{menit} /$ minggu .

\section{1) Pengembangan Model Pengambilan \\ Keputusan Multi Kriteria}

Berdasarkan uji-uji, perhitunganperhitungan, dan peramalan permintaan produk akan didapatkan koefisien, konstanta, dan variable-variabel yang membangun model pengambilan keputusan multi kriteria yang merupakan suatu model optimasi.

a) Variabel keputusan

$X_{1}$ :jumlah produksi minuman A per minggu (karton) 
$X_{2}$ :jumlah produksi minuman $\mathrm{B}$ per minggu (karton)

$X_{3}$ :jumlah produksi minuman $\mathrm{C}$ per minggu (karton)

$X_{4}$ :jumlah produksi minuman $\mathrm{D}$ per minggu (karton)

$X_{5}$ :jumlah produksi minuman $\mathrm{E}$ per minggu (karton)

$X_{6}$ :jumlah produksi minuman $\mathrm{F}$ per minggu (karton)

$X_{7}$ :jumlah produksi minuman $\mathrm{G}$ per minggu (karton)

$X_{8}$ :jumlah produksi minuman $\mathrm{H}$ per minggu (karton)

b) Model matematis fungsi tujuan

- Formulasi minimasi biaya produksi

Min. $Z_{1}=\sum_{i=1}^{8} C_{i} X_{i}$

Keterangan :

$Z_{1}$ : total biaya produksi produk minuman kemasan

$C_{i}$ : biaya produksi untuk produk minuman kemasan ke-i

$X_{i} \quad$ : jumlah produk minuman kemasan ke-i yang diproduksi perusahaan

- Formulasi maksimasi utilitas mesin perebusan

Max. $Z_{2}=\frac{\sum_{i=1}^{8}\left(\frac{(\text { Kebutuhan } / \text { karton }) X_{i}}{\text { Kapasitas } / \text { SK }}\right) \times t a_{i}}{\text { Ketersediaan } S K}$

Keterangan :

$Z_{2}$ : Total penggunaan mesin pada proses perebusan

Kebutuhan/karton : waktu proses setiap karton

Kapasitas/SK : kapasitas stasiun kerja setiap mesin

$t a_{i}$ : waktu proses setiap mesin untuk produk minuman kemasan ke-i

$X_{i} \quad$ : jumlah produk minuman kemasan ke-i

Ketersediaan $S K \quad$ : $\quad$ kapasitas stasiun kerja setiap mesin

- Formulasi maksimasi utilitas mesin penuangan cup

$\operatorname{Max} . Z_{3}=\frac{\sum_{i=1}^{8} t b_{i} X_{i}}{\text { Ketersediaan } S K}$

Keterangan :

$Z_{3}$ : total penggunaan mesin pada proses penuangan cup

$t b_{i}$ : waktu proses setiap mesin untuk produk minuman kemasan ke-i
$X_{i}$ : jumlah produk minuman kemasan ke-i yang diproduksi perusahaan

Ketersediaan $S K \quad: \quad$ kapasitas

stasiun kerja setiap mesin

- Formulasi maksimasi utilitas mesin pengemasan karton

$\operatorname{Max} . Z_{4}=\frac{\sum_{i=1}^{8} t c_{i} X_{i}}{\text { Ketersediaan } S K}$

Keterangan :

$Z_{3}$ : total penggunaan mesin pada proses pengemasan karton

$t c_{i} \quad$ : waktu proses setiap mesin untuk produk minuman kemasan ke-i

$X_{i}$ : jumlah produk minuman kemasan ke-i yang diproduksi perusahaan

Ketersediaan $S K \quad$ : $\quad$ kapasitas stasiun kerja setiap mesin

c) Model matematis fungsi pembatas

- Formulasi fungsi pembatas ketersediaan jam kerja mesin perebusan

$\sum_{i=1}^{8}\left(\frac{(\text { Kebutuhan } / \text { karton }) X_{i}}{\text { Kapasitas } / S K}\right) \times t a_{i} \leq$

TSK 1

Keterangan :

Kebutuhan/karton : waktu proses setiap karton

Kapasitas/SK : kapasitas stasiun kerja setiap mesin

$t a_{i} \quad: \quad$ waktu proses setiap mesin untuk produk minuman kemasan ke-i

$X_{i}$ : jumlah produk minuman kemasan ke-i

TSK 1: kapasitas total waktu pada stasiun kerja perebusan

- Formulasi fungsi pembatas ketersediaan jam kerja mesin penuangan cup

$\sum_{i=1}^{8} t b_{i} X_{i} \leq T S K 2$

Keterangan :

$t b_{i}$ : waktu proses setiap mesin untuk produk minuman kemasan ke-i

$X_{i}$ : jumlah produk minuman kemasan ke-i yang diproduksi perusahaan

TSK2 : kapasitas total waktu pada stasiun kerja penuangan cup

- Formulasi fungsi pembatas ketersediaan jam kerja mesin pengemasan karton

$\sum_{i=1}^{8} t c_{i} X_{i} \leq T S K 3$

Keterangan : 
$t c_{i}$ : waktu proses setiap mesin untuk produk minuman kemasan ke-i

$X_{i}$ : jumlah produk minuman kemasan ke-i yang diproduksi perusahaan

TSK3 : kapasitas total waktu pada stasiun kerja 3

- Formulasi fungsi pembatas produksi minimal

$\sum_{i=1}^{8} X_{i} \geq S_{t}-\left(P_{t-1}-S_{t-1}\right)$

Keterangan :

$X_{i}:$ jumlah produk minuman kemasan ke-i yang diproduksi perusahaan

$S_{t}: \quad$ jumlah permintaan pada periode ke-t

$P_{t-1}$ : jumlah produksi pada periode ke- $t-1$

$S_{t-1}$ : jumlah permintaan/produksi minimal pada periode ke- $t-1$

- Formulasi fungsi pembatas kapasitas warehouse

$$
\sum_{i=1}^{8} X_{i} \leq K W
$$

Keterangan :

$X_{i}:$ jumlah produk minuman perusahaan ke-i

$K W$ : kapasitas warehouse yang dimiliki perusahaan

12) Model pengambilan keputusan muli kriteria yang merupakan model optimasi untuk minggu ke 2 bulan Januari 2021 $\operatorname{Min} Z_{1}=6,576 X_{1}+6.783 X_{2}+6.809 X_{3}$

$$
\begin{aligned}
& +12.125 X_{4}+11.907 X_{5} \\
& +12.231 X_{6}+12.407 X_{7} \\
& +11.875 X_{8}
\end{aligned}
$$

$\operatorname{Max} . Z_{2}$

$$
0,059 X_{1}+0,059 X_{2}+0,064 X_{3}+0,073 X_{4}+0,074 X_{5}
$$$$
+0,074 X_{6}+0,058 X_{7}+0,056 X_{8}
$$

$$
\begin{aligned}
= & \frac{8.200}{\operatorname{Max} . Z_{3}} \\
= & \frac{\left[\begin{array}{c}
0,063 X_{1}+0,063 X_{2}+0,063 X_{3}+0,063 X_{4} \\
+0,063 X_{5}+0,063 X_{6}+0,063 X_{7}+0,063 X_{8}
\end{array}\right]}{8.200}
\end{aligned}
$$

$\operatorname{Max} . Z_{4}$

$$
=\frac{\left[\begin{array}{c}
0,711 X_{1}+0,711 X_{2}+0,711 X_{3}+0,711 X_{4} \\
+0,711 X_{5}+0,711 X_{6}+0,711 X_{7}+0,711 X_{8}
\end{array}\right]}{57.400}
$$

Pembatas

$$
\begin{gathered}
0,059 X_{1}+0,059 X_{2}+0,063 X_{3}+0,073 X_{4} \\
+0,074 X_{5}+0,074 X_{6} \\
+0,057 X_{7}+0,056 X_{8} \\
\leq 8.200 \\
0,062 X_{1}+0,062 X_{2}+0,062 X_{3}+0,062 X_{4} \\
+0,062 X_{5}+0,062 X_{6} \\
+0,062 X_{7}+0,062 X_{8} \leq 8.200 \\
0,711 X_{1}+0,711 X_{2}+0,711 X_{3}+0,711 X_{4} \\
+0,711 X_{5}+0,711 X_{6} \\
+0,711 X_{7}+0,711 X_{8} \leq 57.400 \\
X_{1} \geq 20.457-(0-0) \\
X_{2} \geq 2.543-(0-0) \\
X_{3} \geq 1,742-(0-0) \\
X_{4} \geq 1.928-(0-0) \\
X_{5} \geq 554-(0-0) \\
X_{6} \geq 753-(0-0) \\
X_{7} \geq 321-(0-0) \\
X_{8} \geq 234-(0-0) \\
X_{1}+X_{2}+X_{3}+X_{4}+X_{5}+X_{6}+X_{7}+ \\
X_{8} \leq 36.154 \\
X_{1}, X_{2}, X_{3}, X_{4}, X_{5}, X_{6}, X_{7}, X_{8} \geq 0
\end{gathered}
$$

- Solusi ideal masing-masing fungsi tujuan dicari menggunakan bantuan software LINGO

$Z_{1}^{*}=Z_{1}$ minimal $=\mathrm{Rp} 215.350 .800$ dengan

$X^{1 *}$

$=(21.376,2.462,1.664,1.928,548,764,326,222)$

$Z_{1}$ maksimal $=-Z_{1}$ minimal $=$

$-\mathrm{Rp} 215.350 .800$

$Z_{2}^{*}=Z_{2}$ maksimal $=0,290924$ dengan

$X^{2 *}$

$=(21.376,2.546,1.851,2.083,5.787,925,352,231)$

$Z_{3}^{*}=Z_{3}$ maksimal $=0,272444$ dengan

$X^{3 *}$

$=(21.376,2.462,7.528,1.928,548,764,326,222)$

$Z_{4}^{*}=Z_{4}$ maksimal $=0,446330$ dengan

$X^{4 *}$

$=(21.376,2.462,7.528,1.928,548,764,326,222)$

- Membuat table pay-off

Tabel 9. Tabel payoff

\begin{tabular}{lllll}
\hline & \multicolumn{1}{c}{$\mathrm{X}^{1^{*}}$} & \multicolumn{1}{c}{$\mathrm{X}^{2^{*}}$} & \multicolumn{1}{c}{$\mathrm{X}^{3^{*}}$} & \multicolumn{1}{c}{$\mathrm{X}^{4^{*}}$} \\
\hline $\mathrm{Z}_{1}$ & - & - & - & - \\
& $\mathbf{R p 2 1 5 . 3 5 0 . 8 0 0}$ & $\mathrm{Rp} 283.620 .537$ & $\mathrm{Rp} 254.671 .210$ & $\mathrm{Rp} 254.671 .210$ \\
$\mathrm{Z}_{2}$ & 0,232092 & $\mathbf{0 , 2 9 0 9 2 4}$ & 0,277304 & 0,277304 \\
$\mathrm{Z}_{3}$ & 0,226998 & 0,272420 & $\mathbf{0 , 2 7 2 4 4 4}$ & 0,272436 \\
$\mathrm{Z}_{4}$ & 0,371878 & 0,446292 & 0,446318 & $\mathbf{0 , 4 4 6 3 3 0}$ \\
\hline
\end{tabular}

- Membuat model optimasi global criteriaon method 


$$
\begin{aligned}
& \operatorname{Min} Z=\left[\frac{-215.350 .800-Z_{1}}{-215.350 .800}\right] \\
& +\left[\frac{0,290924-Z_{2}}{0,290924}\right] \\
& +\left[\frac{0,272444-Z_{3}}{0,272444}\right] \\
& +\left[\frac{0,446330-Z_{4}}{0,446330}\right] \\
& 0,059 X_{1}+0,059 X_{2}+0,063 X_{3}+0,073 X_{4} \\
& +0,074 X_{5}+0,074 X_{6} \\
& +0,057 X_{7}+0,056 X_{8} \\
& \leq 8.200 \\
& 0,062 X_{1}+0,062 X_{2}+0,062 X_{3}+0,062 X_{4} \\
& +0,062 X_{5}+0,062 X_{6} \\
& +0,062 X_{7}+0,062 X_{8} \leq 8.200 \\
& 0,711 X_{1}+0,711 X_{2}+0,711 X_{3}+0,711 X_{4} \\
& +0,711 X_{5}+0,711 X_{6} \\
& +0,711 X_{7}+0,711 X_{8} \leq 57.400 \\
& X_{1} \geq 20.457-(0-0) \\
& X_{2} \geq 2.543-(0-0) \\
& X_{3} \geq 1.742-(0-0) \\
& X_{4} \geq 1.928-(0-0) \\
& X_{5} \geq 554-(0-0) \\
& X_{6} \geq 753-(0-0) \\
& X_{7} \geq 321-(0-0) \\
& X_{8} \geq 234-(0-0) \\
& X_{1}+X_{2}+X_{3}+X_{4}+X_{5}+X_{6}+X_{7}+ \\
& X_{8} \leq 36.154 \\
& X_{1}, X_{2}, X_{3}, X_{4}, X_{5}, X_{6}, X_{7}, X_{8} \geq 0 \\
& \text { Menggunakan software LINGO } \\
& \text { menghasilkan solusi optimal: } \\
& X^{*} \\
& Z^{*}=-215.350 .800 \text { dengan } \\
& =(21.376,2.582,7.407,1.928,548,764,326,222) \\
& Z_{4}=0,446318
\end{aligned}
$$

Sehingga rencana produksi optimal pada minggu ke 2 Januari 2021 dapat dilihat pada table berikut.
Tabel 10. Rencana Produksi Minggu ke 2 Januari 2021

\begin{tabular}{ccccc}
\hline \multirow{2}{*}{ Produk } & \multicolumn{4}{c}{ Minggu ke 2 Januari 2021 } \\
\cline { 2 - 5 } & $\begin{array}{c}\text { Persedi } \\
\text { aan }\end{array}$ & $\begin{array}{c}\text { Permin } \\
\text { taan }\end{array}$ & $\begin{array}{c}\text { Minimal } \\
\text { Produksi }\end{array}$ & Produksi \\
\hline Minuman A & 0 & 20.457 & 20.457 & 20.457 \\
Minuman B & 0 & 2.543 & 2.543 & 2.543 \\
Minuman C & 0 & 1.742 & 1.742 & 1.742 \\
Minuman D & 0 & 1.928 & 1.928 & 1.928 \\
Minuman E & 0 & 554 & 554 & 554 \\
Minuman F & 0 & 753 & 753 & 753 \\
Minuman G & 0 & 321 & 321 & 321 \\
Minuman h & 0 & 234 & 234 & 234 \\
\hline
\end{tabular}

\subsection{Analisis Hasil}

Pengembangan model pengambilan keputusan multi kriteria yang dibangun telah dapat meminimasi biaya produksi dan memaksimasi utilitas mesin pada Perusahaan Minuman Kemasan X. Pengembangan model yang dilakukan dengan melakukan peramalan permintaan produk akan berakibat pada kecilnya deviasi antara produksi yang direncanakan dengan permintaan actual produk. Pengembangan model yang dilakukan juga telah memasukkan ketersediaan kapasitas gudang sebagai suatu pembatas, sehingga rencana produksi yang dilakukan tidak akan melebihi kapasitas gudang, sehingga akan meminimalkan biaya simpan.

Solusi kompromi Z1 dapat dilihat bahwa nilainya tidak lebih kecil dari pada $\mathrm{Z1}$ *, sehingga hal ini valid karena fangsi tujuan dari Z1 adalah minimasi. Unrtuk solusi kompromi Z2, Z3, dan Z4 nilanya tidak lebih besar dari pada $Z 2^{*}, Z 3^{*}$, dan $Z 4^{*}$, sehingga hal ini valid karena fungsi tujuan dari Z2, Z3, dan Z4 adalah maksimasi.

Deviasi antara solusi kompromi minimasi biaya produksi dengan nilai ideal biaya produksi adalah $|254.630 .420-215.350 .800|=$ 39.279.620. Deviasi antara solusi kompromi maksimasi utilitas mesin stasiun kerja 1 dengan nilai idealnya adalah $\mid 0,277221$ $0,290924 \mid=0,013703$. Deviasi antara solusi kompromi maksimasi utilitas mesin stasiun kerja 2 dengan nilai idealnya adalah $\mid 0,272436$ - 0,272444 $\mid=0,000008$. Deviasi antara solusi kompromi maksimasi utilitas mesin stasiun kerja 2 dengan nilai idealnya adalah $\mid 0,446318$ - $0,446330 \mid=0,000012$. 


\section{KESIMPULAN DAN SARAN}

Penelitian ini telah dapat mengembangkan model pengambilan keputusan multi kriteri untuk meminimasi biaya produksi dan memaksimalkan utilitas mesin. Model pengambilan keputusan multi kriteria yang dikembangkan akan meminimalkan biaya produksi dan juga memaksimalkan utilitas mesin. Model pengambilan keputusan multi kriteria yang dikembangkan akan membuat rencana produksi yang dijalankan akan dapat mendekati permintaan actual dan tidak melebihi kapasitas gudang.

Dengan menggunakan step method telah didapatkan solusi kompromi untuk model pengambilan keputusan multi kriteria yang sudah dikembangkan, sehingga dapat diketahui deviasi antara solusi kompromi yang dihasilkan terhadap nilai idealnya. Untuk membandingkan deviasi yang diperoleh maka dapat dilakukan pencarian solusi kompromi pada model pengambilan keputusan multi kriteria yang dikembangkan ini menggunakan metode yang lain.

\section{DAFTAR PUSTAKA}

Abdullah, R. (2018), Analisis Upaya Pengambilan Keputusan dalam Memilih Supplier Terbaik dengan Metode AHP (Analytical Hierarchy Process) Pada Departemen Procurement PT. XYZ, Seminar Nasional Sains dan Teknologi 2018, Fakultas Teknik Universitas Muhammadiyah Jakarta, 17 Oktober 2018, Jakarta

Amin, R., Mustika, W.P., 2017, Model Pengambilan Keputusan Berbasis Kriteria Majemuk dalam Pemilihan Investasi Ideal Bagi Masyarakat, Journal Industrial Servicess Vol. 3 No. 1b Oktober 2017

Cinelli, M., Coles, S. R., Kirman, K., (2014), Analysis of The Potentials of MultiCriteria Decision Analysis Methods to Conduct Sustainability Assessment, Ecological Indicators, Elsevier, Volume 46, Pages 138-148
Doaly, C.O., Moengin, P., Chandiawan, G., 2019, Pemilihan Multi-Kriteria Pemasok Departemen Store Menggunakan Metode Fuzzy AHP dan TOPSIS, Jurnal Ilmiah Teknik Industri, Vol. 7 No. 1, $70-78$

Handayani, T., Wakhidah, N., (2012), Penerapan SPK Untuk Seleksi Mahasiswa Berprestasi Menggunakan Metode AHP, Jurnal Universitas Semarang, Volume 1 Nomor 2

Huang, I.B., Keisler. J., Linkov, I., (2011), Multi-Criteria Decision Analysis in Environmental Science : Ten Years of Applications and Trends, Science of The Total Environment, Elsevier, Volume 409, Issues 19, Pages 3578 - 3594

Indrianti, N., Sutrisno, (2014), Buku Ajar Pengambilan Keputusan Multi Kriteria, UPN "Veteran" Yogyakarta, Yogyakarta

Jiang, W.Y., Chun, Y.J., Jun, F.Z., Zhao, H., (2009), Review on Multi-Criteria Decision Analysis Aid in Sustainable Energy Decision-making, Renewable and Sustainable Energy Reviews, Elsevier, Vol 13, Issue 9, Pages 2263 - 2278

Kurniawan, E., Ilmi, A.M., Balafif, N., 2020, Implementasi Multi Criteria Decision Making Menggunakan Metode Simple Additive Weighting (SAW) Pada Sistem Pendukung Keputusan Promosi Kenaikan Jabatan, Jurnal Teknika, Volume 12, No.1

Safrizal, Tanti, L., 2016, Multi-Criteria Decision Making Dalam Penentuan Jurusan Siswa Pada Lembaga Pendidikan dan Pelatihan (LPP) Penerbangan, Journal of Applied Intelligent System, Vol.1, No. 3, Oktober 2016: 154-166

Si, J., Halburd, L.M., Nasiri, F., Bell, S., (2016), Assessment of Building-integrated Green Technologies: A Review and Case Study on Applications of Multi-Criteria Decision Making (MCDM) Method, Sustainable Cities and Society, Elsevier, Vol 27, Pages $106-115$ 